\title{
The Effect of Molybdenum and Iron on Nodulation, Nitrogen Fixation and Yield of Chickpea Genotypes (Cicer Arietinum L)
}

\author{
Nawaz Khan ${ }^{1}$, Muhammad Tariq ${ }^{1}$, Khitab Ullah ${ }^{1}$, Dost Muhammad ${ }^{1}$, \\ Imran Khan ${ }^{1}$, Kamran Rahatullah ${ }^{2}$, Nazeer Ahmed ${ }^{3}$ and Saeed Ahmed ${ }^{4}$ \\ ${ }^{1}$ Department of Soil and environmental sciences, The university of Agriculture, Peshawar-Pakistan, \\ ${ }^{2}$ Department of Food science and technology, The university of Agriculture, Peshawar- \\ Pakistan, ${ }^{3}$ Department of Entomology, The University of Agriculture, Peshawar-Pakistan, \\ ${ }^{4}$ Department of Horticulture, The University of Agriculture, Peshawar-Pakistan
}

\begin{abstract}
The present study was based on the hypothesis that the applied molybdenum and iron influence the nodulation, nitrogen fixation and yield by chickpea genotypes. For this purpose a field experiment was conducted to study the influence of different levels of molybdenum and iron on the nodulation, nitrogen fixation and yield of chickpea genotypes (Cicer arietinum L.) growing two different genotypes such as Desi (sheenghar) and Kabuli (Karak-II) during, 2011-12 at Malakandher Farm, The University of Agriculture, Peshawar. Different levels of molybdenum and iron were applied at the rate of $0,0.25$ and 0.50 and 0,2 and $5.0 \mathrm{~kg} \mathrm{ha}^{-1}$, respectively along with a basal dose of $25 \mathrm{~N}, 60 \mathrm{P}_{2} \mathrm{O}_{5}$ and $60 \mathrm{~K}_{2} \mathrm{O}$ in randomized complete block design with split plot arrangement and replicated three times. Results revealed that maximum yield and yield parameters, numbers of root nodules and nitrogen concentration were observed in those treatment plots where Mo 0.5 and Fe $2.0 \mathrm{~kg} \mathrm{ha}^{-1}$ were applied simultaneously for both genotypes. The grain yield, nodulation and nitrogen concentration were recorded significantly more in Kabuli (Karak-II) as compared to Desi (sheenghar) of chickpea genotypes, perhaps due to the formation of maximum nodulation and nitrogen concentration by plants. Results revealed that with increasing the levels of Mo and Fe in soil, the concentration of Fe and $N$ in plant leaves were significantly increased in both genotypes at flowering stage. Moreover, in the present study the number of nodules were correlated with $N$ concentration of plants for both genotypes and found as the nodules formation increases the plant $N$ concentration linearly increased and showed close relationship with one another. Similarly, the Fe-concentration increases in plant leaves, $N$-concentration also increases in a similar fashion, indicated that Fe-played a vital role in $\mathrm{N}$-fixation by chickpea genotypes. The present study suggests that the application of Mo 0.5 and Fe $2.0 \mathrm{~kg} \mathrm{ha}^{-1}$ is important which play a significant role in getting the maximum yield, nodules and nitrogen concentration in chickpea genotypes.
\end{abstract}

\section{Introduction}

Chickpea (Cicer arietinum L.) is an annual legume belongs to family Leguminoseae and is grown throughout the world for grain pulse. There are two main kinds of chickpea Desi and Kabuli. Desi, has small, darker seeds and a rough coat, grown mostly in semi-arid regions, while Kabuli has lighter coloured, larger seeds with smoother coat, mainly grown in temperates regions of Pakistan. Chickpea is leguminous crop which fix nitrogen in the root nodules; and this process depend on various factors, like molybdenum and iron nutrition which play a key role in symbiotic nitrogen fixation by legumes. Chickpea is an important cool season legume of arid tropics due to its ability to fix atmosphere nitrogen, it is considered to sustain cropping system productivity. This crop having nodules on their roots where some bacteria, called rhizobia live with a specific function to fix atmosphere nitrogen into plant available form called biological nitrogen fixation. By this process a maximum amount of free lost nitrogen is deposited in to the soil which can be used by the same plant and the next can also. The maximum nitrogen fixation by the crop depend upon the cultivar, nodules numbers, nodule weight and the efficient strain of bacteria survive in their root nodules. Sufficient amount of nitrogen can be fix by the chickpea to replace the removed nitrogen in harvested grains (FAO, 1984; Schwenke et al., 1998). It contains sufficient amount of protein that meets protein requirement of the bulk of population of our country (Shah et al., 1998).

Molybdenum is required for growth of most biological organisms including plants (Graham and Stangoulis, 2005). Generally, molybdenum is an essential micronutrient for plants and bacteria (Williams and Fraustoda Silva 2002). Meagher et al. (1991) reported the role of molybdenum in normal assimilation of nitrogen by plants is well known, because molybdenum is an essential component of nitrate reductase and nitogenase, which control the reduction of inorganic nitrate and helps in fixing $\mathrm{N}_{2}$ to $\mathrm{NH}_{3}$. Thus, molybdenum is the key to nitrogen fixation by legumes. Brkics et al. (2004) and Jongruaysup et al. (1993) also stated that the application of molybdenum stimulated nodulation and biological nitrogen fixation, thus increasing the legume 
yield. Moreover, Katyal and Randhawa (1983) stated that molybdenum is required in the synthesis of ascorbic acid is implicated in making iron physiologically available.

Similarly, iron plays a key role in several enzyme systems in which haem or haemin functions as the prothectic group. These haem enzyme systems comprise the catalases, peroxidases and several cytochromes. Cytochromes operate the respiratory metabolism of living cell. Among the haem Fe enzyme is ferredoxin which regulates oxidation reduction reaction its role in photosynthesis, $\mathrm{NO}_{2}^{-}$and $\mathrm{SO}_{4}^{-2}$ reduction and nitrogen assimilation underlines the vital functions iron performs in over all plant metabolism. Iron deficiencies are mainly manifested by yellow leaves due to low levels of chlorophyll. Leaf yellowing first appears on the younger upper leaves in interveinal tissues. Severe iron deficiencies cause leaves to turn completely yellow or almost white, and then brown as leaves die. Hageman and Burris (1978) reported that the enzyme nitrogenase contained two proteins: Fe protein (component containing iron and protein) and Mo-Fe protein (component containing molybdenum, iron and protein). Therefore, iron and cobalt are essential for the nitrogen fixation process (Meagher et al., 1991).

Haque et al. (1979) reported that micronutrients molybdenum and iron are very important for chickpea and other legumes to fix atmospheric nitrogen because molybdenum and iron are essential constituents of nitrogenase enzyme which is responsible for biological nitrogen fixation and their deficiency in soil may affect nitrogen fixation and yield of chickpea.

In alkaline-calcareous soils, the yield of grain legumes specifically chickpea crop is often limited by lower availability of molybdenum and iron, especially when they depend upon symbiosis with root nodules bacteria for their nitrogen nutrition. However, the effect of molybdenum and iron limitation upon nitrogen fixation are not fully understood in the indigenous conditions for leguminous crop like chickpea, therefore keeping in view, the nutritional importance of molybdenum and iron on nitrogen fixation by chickpea crop, a field experiment was carried out in Malakandher Farm The university of Agriculture, Peshawar with the following main objectives:-

\section{Objectives}

- To determine the effect of applied molybdenum and iron on the yield and yield parameters of chickpea genotypes.

- To study the effect of applied molybdenum and iron on root nodulation chickpea genotypes.

- To find out the effect of applied molybdenum and iron on the uptake of nitrogen by chickpea genotypes.

\subsection{Experimental description}

\section{Materials and Methods}

A field experiment was conducted at Malakandher Farm, The University of Agriculture Peshawar, during 3rd November, 2011 to study the effect of molybdenum and iron on the nitrogen fixation by two chickpea genotypes, such as Desi (Sheenghar) and Kabuli (Karak-II). The chickpea seeds were sown in randomized complete block design with split plot arrangement and replicated 3times. A plot size was $6 \mathrm{~m}^{2}$. Each plot was comprised of 3 rows containing row to row distance of $30 \mathrm{~cm}$ and plant to plant distance was of $20 \mathrm{~cm}$. Different levels of molybdenum at the rate of $0,0.25$ and 0.5 and iron at the rate of 0,2 and $5 \mathrm{~kg} \mathrm{ha}^{-1}$ was applied in the form of ammonium molybdate and iron sulfate, respectively. A basal dose of $25 \mathrm{~N}, 60 \mathrm{P}_{2} \mathrm{O}_{5}$ and $60 \mathrm{~K}_{2} \mathrm{O} \mathrm{kg} \mathrm{ha}{ }^{-1}$ was applied in the form of urea, di ammonium phosphate and potassium sulfate before sowing. Before fertilizer application a composite soil sample was collected for the determination of physico-chemical characteristics and desired nutrients status of the test soil.

Table 3.1 Physico-chemical characteristics of the experimental soil

\begin{tabular}{|l|l|l|}
\hline Properties & Units & Values \\
\hline Sand & $\%$ & 21.98 \\
\hline Silt & $\%$ & 54.42 \\
\hline Clay & $\%$ & 23.60 \\
\hline Textural class & - & Silt Loam \\
\hline $\mathrm{pH}_{\mathrm{s}(1: 5)}$ & - & 7.98 \\
\hline $\mathrm{EC}_{\mathrm{s}(1: 5)}$ & $\mathrm{dSm}^{-1}$ & 0.24 \\
\hline Lime & $\%$ & 9.34 \\
\hline Organic matter & $\%$ & 0.68 \\
\hline Total mineral nitrogen $\left(\mathrm{NH}_{4}-\mathrm{N}+\mathrm{NO}_{3}-\mathrm{N}\right)$ & $\%$ & 0.065 \\
\hline Fe $($ AB-DTPA) & $\mathrm{mg} \mathrm{kg}{ }^{-1}$ & 4.33 \\
\hline
\end{tabular}


The physico-chemical characteristics of the experimental soil (Table 3.1) shows that the soil was silt loam in texture, alkaline in reaction, non-saline in nature, low in organic matter content, moderately calcareous and slightly deficient in available-N, while soluble Fe was adequate (Katyal and Randhawa 1982).

All culture practices were performed when required. Data on the following parameters were recorded during field and laboratory investigations:-

- $\quad$ Days to emergence

- Days to flowering

- Shoot biomass

- $\quad$ Seed yield

- Number of pods plant ${ }^{-1}$

- Number of seeds pod ${ }^{-1}$

- 100 seeds weight

- $\quad$ Fresh mass of nodules plant ${ }^{-1}$

- Number of nodules plant ${ }^{-1}$

- $\quad \mathrm{N}$ concentration in plant leaves

- $\quad \mathrm{N}$ uptake by plant

- $\quad$ Fe concentration in plant leaves

- $\quad$ Fe uptake by plant

\subsection{Soil analysis}

The physico-chemical properties of the experimental site such as soil texture (Gee and Budr, 1982), soil pH (McLean, 1982), electrical conductivity (Rhoades, 1982), lime (Cottenie, 1980) and organic matter (Nelson and Sommers, 1996) contents were measured using the standard routine methods following in the laboratory of Soil and Environmental Sciences.

\subsection{Plant analysis}

At flowering stage, fully developed leaves from each treatment plot were collected from randomly selected plants (5) for the determination of elemental $\mathrm{N}$ and Fe concentration. Fresh leaves were washed with distilled water, blotted with tissue paper and air dried in open air under shade. The samples were then oven dried at $70^{\circ} \mathrm{C}$ for $48 \mathrm{~h}$ to a constant weight. The leaves were chopped with a mini grinder followed by wet acid digestion of leaves by procedure of Benton et al. (1991). The total $\mathrm{N}$ concentration in leaves was determined by micro Kjeldhal apparatus as described by Mulvaney (1996). While Fe concentration was estimated by atomic absorption spectrophotometer (Issac and Kerber, 1971).

\subsubsection{Nitrogen concentration}

Total nitrogen in soil and plant simple was determined by the Kjeldahl method of Bremner and Mulvaney (1982).In this method, $0.2 \mathrm{~g}$ of soil or plant simple was digested with $3 \mathrm{ml}$ of concentrated $\mathrm{H}_{2} \mathrm{SO}_{4}$ in the presence of $1.1 \mathrm{~g}$ digestion mixture containing $\mathrm{K}_{2} \mathrm{SO}_{4}, \mathrm{CUSO}_{4}$ and $\mathrm{Se}$ on block digestion for about 4-5 hours. After cooling, the digest was transferred quantitatively to a $100 \mathrm{ml}$ volumetric flask and made the volume using distilled water. $20 \mathrm{ml}$ of the digest was distilled in presence of $5 \mathrm{ml}$ of $40 \% \mathrm{NaOH}$ solution into a $5 \mathrm{ml}$ boric acid mixed indicator solution. The distillate was titrated against standard $0.005 \mathrm{M} \mathrm{HCl}$. Blank was also run at the same time and subtracted its reading from the simple. The amount of nitrogren was calculated using the following expression:

$$
\text { Total N }(\%)=\underline{(\text { Sample }- \text { Blank }) \times 0.005 \times 0.014 \times 100 \times 100}
$$

Weight of plant sample $\mathrm{x} 20$

$\mathrm{S}=$ volume of acid $(0.1 \mathrm{~N})$ used for sample

$\mathrm{B}=$ volume of acid $(0.1 \mathrm{~N})$ used for blank

\subsubsection{Iron concentration}

Iron concentration in chickpea leaves was determined in digested sample using atomic absorption spectrophotometer (Perkin Elmer 2380) a $0.25 \mathrm{~g}$ sample was digested with nitric acid and perchloric acid as suggested by Walsh and Beaton (1977).

\section{Statistical analysis}


The statistical analysis of data was carried out by conducting ANOVA and the treatment differences were estimated by LSD-test of significance. In addition, multiple regression models were used to find out the relationship between fixed $\mathrm{N}$ in plants and applied Mo-Fe to soil (Steel et al., 1997).

\section{Results And Discussion}

The effect of different levels of molybdenum (Mo) and iron $(\mathrm{Fe})$ was evaluated on the yield, nodulation and nitrogen concentration of chickpea crop under agro-climatic conditions of Malakandher Farm, The University of Agriculture, Peshawar, during Rabbi 2011-2012. The test verities were Sheenghar and Karak-II. The field and laboratory findings are presented in Tables 4.1 to 4.13 along with Figures 4.1 to 4.6 and complete analysis of variance along with replication wise data for each parameter is given in Appendices 1 to 13.The results obtained are presented and discussed in the following sections.

\subsection{Days to emergence}

Nutrients uptake and yield of plants were directly affected by seed emergence. Non significant differences were observed among the different combination of molybdenum and iron. The data regarding to days to germination from the date of sowing are given in (Table 4.1a). The emergence data were recorded after 7 days of sowing. Maximum days (11 days) were taken by Sheenghar as compared to Karak-II and this difference was probably due to climatic effect i.e. continuous rainfall on crop genotypes or genetic factor not due to nutritional problem of the seed. However, in the treatment plots where no molybdenum was applied took more days to emergence for both chickpea genotypes. Due to the different levels of iron ranging from complete deficiency to toxicity, increased or decreased the growth rate and physiological components were reported by Nenova, (2006). The emergence was delay due to environmental factors i.e. absence of sun light and continues rainfall during the experimental time. Results also showed that the emergence rate in molybdenum and iron plots were comparatively better than those plots, which received no molybdenum and iron fertilizer as shown in Figure 4.1.

Table 4.1a Effect of molybdenum and iron application on the days to emergence of chickpea genotypes

\begin{tabular}{|c|c|c|c|c|c|}
\hline \multirow[b]{3}{*}{ Genotypes } & \multirow{3}{*}{$\begin{array}{c}\text { Mo } \\
\left(\mathrm{kg} \mathrm{ha}^{-1}\right)\end{array}$} & \multicolumn{3}{|c|}{$\mathrm{Fe}\left(\mathrm{kg} \mathrm{ha}^{-1}\right)$} & \multirow{3}{*}{$\begin{array}{c}\text { Mean } \\
(\mathrm{V} x \mathrm{Mo})\end{array}$} \\
\hline & & 0 & 2 & 5 & \\
\hline & & \multicolumn{3}{|c|}{$(\mathrm{V} \times \mathrm{Mo} \times \mathrm{Fe})$} & \\
\hline \multirow{10}{*}{ Karak-II } & 0 & 10.5 & 10 & 11 & 10.5 \\
\hline & 0.25 & 9.3 & 9 & 10.3 & 9.5 \\
\hline & 0.5 & 9.3 & 10 & 10.4 & 9.9 \\
\hline & 0 & 10.3 & 10.2 & 10.7 & 10.4 \\
\hline & 0.25 & 10.3 & 10 & 10.6 & 10.3 \\
\hline & 0.5 & 9.5 & 9 & 10.6 & 9.7 \\
\hline & & \multicolumn{3}{|c|}{$(\mathrm{Mo} \times \mathrm{Fe})$} & (Mo) \\
\hline & 0 & 10.4 & 10.1 & 10.9 & 10.5 \\
\hline & 0.25 & 9.8 & 9.5 & 10.5 & 9.9 \\
\hline & 0.5 & 9.4 & 9.5 & 10.5 & 9.8 \\
\hline & & \multicolumn{3}{|c|}{$(\mathrm{V} \times \mathrm{Fe})$} & $(\mathrm{V})$ \\
\hline \multirow{2}{*}{\multicolumn{2}{|c|}{$\begin{array}{l}\text { Sheenghar } \\
\text { Karak-II }\end{array}$}} & 9.7 & 9.7 & 10.6 & 10.0 \\
\hline & & 10.0 & 9.7 & 10.6 & 10.1 \\
\hline \multicolumn{2}{|l|}{ Mean } & 9.9 & 9.7 & 10.6 & \\
\hline
\end{tabular}

LSD value of $\mathrm{P}<0.05$ for genotypes $=0.28$

Table 4.1bEffect of molybdenum and iron application on the \% emergence of chickpea genotypes

\begin{tabular}{|c|c|c|c|c|c|c|c|}
\hline Verities & \multicolumn{2}{|c|}{ Treatments } & \multirow{3}{*}{ D7 } & \multirow{3}{*}{ D8 } & \multirow{3}{*}{ D9 } & \multirow{3}{*}{ D10 } & \multirow{3}{*}{ D11 } \\
\hline \multirow[t]{11}{*}{ Sheenghar } & Mo & $\mathbf{F e}$ & & & & & \\
\hline & \multicolumn{2}{|c|}{$\left(\mathrm{kgha}^{-1}\right)$} & & & & & \\
\hline & \multirow[t]{3}{*}{0} & 0 & 24.0 & 43.0 & 64.7 & 76.0 & 83.3 \\
\hline & & 2 & 24.3 & 40.0 & 67.0 & 79.0 & 84.0 \\
\hline & & 5 & 23.3 & 40.3 & 63.0 & 79.0 & 81.3 \\
\hline & \multirow[t]{3}{*}{0.25} & 0 & 24.3 & 41.3 & 66.0 & 80.0 & 86.3 \\
\hline & & 2 & 25.0 & 43.0 & 67.0 & 79.7 & 87.3 \\
\hline & & 5 & 23.7 & 42.0 & 67.7 & 79.0 & 86.3 \\
\hline & \multirow[t]{3}{*}{0.5} & 0 & 24.3 & 43.7 & 68.7 & 80.7 & 86.0 \\
\hline & & 2 & 26.0 & 45.3 & 69.7 & 81.3 & 89.3 \\
\hline & & 5 & 24.0 & 43.7 & 68.3 & 80.0 & 86.0 \\
\hline
\end{tabular}




\begin{tabular}{|c|c|c|c|c|c|c|c|}
\hline \multirow[t]{9}{*}{ Karak-II } & \multirow[t]{3}{*}{0} & 0 & 28.0 & 42.3 & 66.3 & 72.7 & 82.0 \\
\hline & & 2 & 26.3 & 43.3 & 67.0 & 75.3 & 83.3 \\
\hline & & 5 & 27.0 & 44.3 & 70.0 & 74.3 & 81.3 \\
\hline & \multirow[t]{3}{*}{0.25} & 0 & 25.7 & 47.0 & 70.7 & 74.3 & 86.7 \\
\hline & & 2 & 29.3 & 49.0 & 71.0 & 80.7 & 88.3 \\
\hline & & 5 & 28.3 & 48.3 & 69.0 & 78.0 & 86.7 \\
\hline & \multirow[t]{3}{*}{0.5} & 0 & 26.7 & 50.3 & 70.0 & 79.0 & 85.7 \\
\hline & & 2 & 30.7 & 51.0 & 72.7 & 81.3 & 90.3 \\
\hline & & 5 & 25.0 & 47.3 & 70.0 & 80.3 & 88.7 \\
\hline \multicolumn{3}{|c|}{ LSD $(\mathrm{P}<0.05)$} & $\mathrm{NS}$ & NS & 2.25 & NS & $\mathrm{NS}$ \\
\hline \multicolumn{3}{|l|}{$\% \mathrm{CV}$} & 13.71 & 10.92 & 8.19 & 7.27 & 5.23 \\
\hline
\end{tabular}

$\mathrm{NS}=$ Non significant
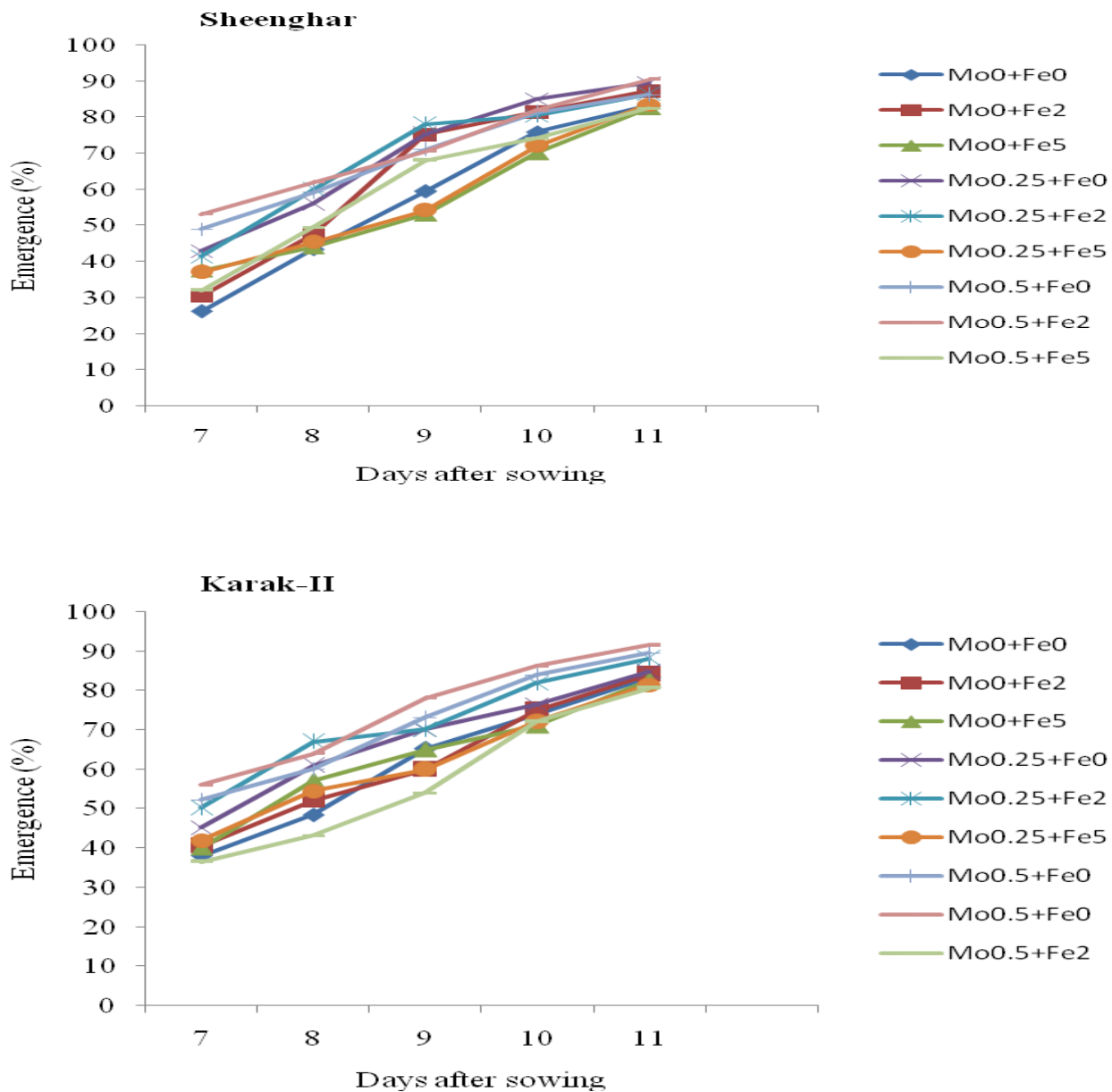

Figure 4.1 Effect of applied molybdenum and iron on the \% emergence of chickpea genotypes

\subsection{Days to flowering}

The data pertaining to number of days to flowering are given in Table 4.2a. Non significant differences were observed between chickpea genotypes in terms of days to flowering. After 130 days of sowing the flowering data were recorded. The maximum numbers of days (138 days) for flowering were recorded in control, while the minimum numbers of days to flowering (133 days) were observed where Mo 0.5 and $\mathrm{Fe} 2 \mathrm{~kg}$ $\mathrm{ha}^{-1}$ were applied in both genotypes of chickpea. Furthermore, statistically no differences in days to flowering were recorded between chickpea genotypes. These results are supported by the previous work of Tahir et al., (2011). Moreover, the treatment plots where no molybdenum was applied took more days to flowering. It showed that the unavailability of molybdenum reduced the days to flowering of chickpea crop. Same observations were reported by Nautiyal et al., (2005). They observed that the low availability of molybdenum is known to disrupt formation development and viability of pollen grains. Therefore the number and size of flowers were reduced and consequently the seed yield was also decreased significantly. Generally, genotypes Sheenghar took more days to flowering than Karak-II, which may be due to genetic difference not due to nutritional on chickpea genotypes. Yield and uptake of nutrients by plants were directly affected by flowering. Flowering data also shows that the emergence rates in molybdenum and iron plots were comparatively better 
than those plots, which received no molybdenum and iron fertilizer as shown in Figure 4.2. Similar observations were reported by Truong and Duthion (1993).

Table 4.2a Effect of molybdenum and iron application on days to flowering of chickpea genotypes

\begin{tabular}{|c|c|c|c|c|c|}
\hline \multirow[b]{3}{*}{ Genotypes } & \multirow{3}{*}{$\begin{array}{c}\text { Mo } \\
\left(\mathrm{kg} \mathrm{ha}^{-1}\right)\end{array}$} & \multicolumn{3}{|c|}{$\mathrm{Fe}\left(\mathrm{kg} \mathrm{ha}^{-1}\right)$} & \multirow{3}{*}{$\begin{array}{c}\text { Mean } \\
(\mathrm{V} \times \mathrm{Mo})\end{array}$} \\
\hline & & 0 & 2 & 5 & \\
\hline & & \multicolumn{3}{|c|}{$(\mathrm{V} \times \mathrm{Mo} \times \mathrm{Fe})$} & \\
\hline \multirow[t]{10}{*}{ Sheeenghar } & 0 & 138 & 135.5 & 135.7 & 136.4 \\
\hline & 0.25 & 136 & 136 & 136 & 136.0 \\
\hline & 0.5 & 136 & 135 & 137.5 & 136.2 \\
\hline & 0 & 138 & 136 & 137 & 137.0 \\
\hline & 0.25 & 137 & 135 & 137.2 & 136.4 \\
\hline & 0.5 & 137 & 134 & 137.3 & 136.1 \\
\hline & & \multicolumn{3}{|c|}{$(\mathrm{Mo} \times \mathrm{Fe})$} & (Mo) \\
\hline & 0 & 138.0 & 135.8 & 136.4 & 136.7 \\
\hline & 0.25 & 136.5 & 135.5 & 136.6 & 136.2 \\
\hline & 0.5 & 136.5 & 134.5 & 137.4 & 136.1 \\
\hline & & \multicolumn{3}{|c|}{$(\mathrm{V} \times \mathrm{Fe})$} & $(\mathrm{V} \times \mathrm{Fe})$ \\
\hline \multirow{2}{*}{\multicolumn{2}{|c|}{$\begin{array}{l}\text { Sheenghar } \\
\text { Karak-II }\end{array}$}} & 136.7 & 135.5 & 136.4 & 136.2 \\
\hline & & 136.7 & 135.7 & 136.8 & 136.4 \\
\hline \multicolumn{2}{|l|}{ Mean } & 136.7 & 135.6 & 136.6 & \\
\hline
\end{tabular}

LSD value of $\mathrm{P}<0.05$ for $\mathrm{Mo}=9.56$

$\mathrm{LSD}$ value of $\mathrm{P}<0.05$ for $\mathrm{Fe}=1.54$

Table 4.2b Effect of molybdenum and iron application on the days to flowering of chickpea genotypes

\begin{tabular}{|c|c|c|c|c|c|c|c|c|}
\hline \multirow{2}{*}{$\begin{array}{c}\text { Verities } \\
\text { Sheenghar }\end{array}$} & \multicolumn{2}{|c|}{ Treatments } & \multirow{3}{*}{ D130 } & \multirow{3}{*}{ D131 } & \multirow{3}{*}{ D132 } & \multirow{3}{*}{ D133 } & \multirow{3}{*}{ D134 } & \multirow{3}{*}{ D135 } \\
\hline & Mo & $\mathrm{Fe}$ & & & & & & \\
\hline & \multicolumn{2}{|c|}{$\left(\right.$ kgha $\left.^{-1}\right)$} & & & & & & \\
\hline & \multirow[t]{3}{*}{0} & 0 & 13.7 & 27.0 & 37.3 & 54.0 & 64.0 & 81.0 \\
\hline & & 2 & 15.3 & 26.7 & 37.0 & 55.0 & 65.0 & 80.0 \\
\hline & & 5 & 14.3 & 25.3 & 38.3 & 52.7 & 62.7 & 81.0 \\
\hline & \multirow[t]{3}{*}{0.25} & 0 & 14.3 & 26.7 & 39.7 & 55.7 & 67.7 & 82.0 \\
\hline & & 2 & 16.0 & 26.0 & 41.0 & 56.0 & 68.7 & 86.3 \\
\hline & & 5 & 15.3 & 26.7 & 37.7 & 53.0 & 66.0 & 81.7 \\
\hline & \multirow[t]{3}{*}{0.5} & 0 & 14.7 & 27.3 & 36.7 & 54.7 & 66.3 & 81.7 \\
\hline & & 2 & 16.0 & 28.7 & 43.3 & 57.7 & 69.0 & 89.0 \\
\hline & & 5 & 14.7 & 26.3 & 38.0 & 55.7 & 66.0 & 80.0 \\
\hline \multirow[t]{9}{*}{ Karak-II } & \multirow[t]{3}{*}{0} & 0 & 15.3 & 26.3 & 37.5 & 54.3 & 68.7 & 76.7 \\
\hline & & 2 & 15.7 & 26.3 & 36.9 & 56.3 & 69.3 & 79.7 \\
\hline & & 5 & 16.0 & 25.7 & 39.6 & 53.0 & 68.7 & 80.3 \\
\hline & \multirow[t]{3}{*}{0.25} & 0 & 16.0 & 27.7 & 36.2 & 56.3 & 68.0 & 82.7 \\
\hline & & 2 & 15.7 & 27.3 & 47.5 & 57.7 & 70.0 & 85.0 \\
\hline & & 5 & 15.3 & 26.3 & 45.5 & 53.0 & 68.0 & 83.0 \\
\hline & \multirow[t]{3}{*}{0.5} & 0 & 16.0 & 27.0 & 39.0 & 53.0 & 67.0 & 84.3 \\
\hline & & 2 & 17.0 & 28.7 & 55.8 & 59.0 & 71.3 & 87.7 \\
\hline & & 5 & 16.3 & 27.0 & 43.5 & 56.3 & 68.0 & 80.3 \\
\hline \multicolumn{3}{|l|}{ LSD $(P<0.05)$} & NS & NS & NS & 2.04 & 3.21 & NS \\
\hline \multicolumn{3}{|l|}{$\% \mathrm{CV}$} & 15.83 & 8.67 & 744 & 5.26 & 3.81 & 4.12 \\
\hline
\end{tabular}

NS = Non-significant 

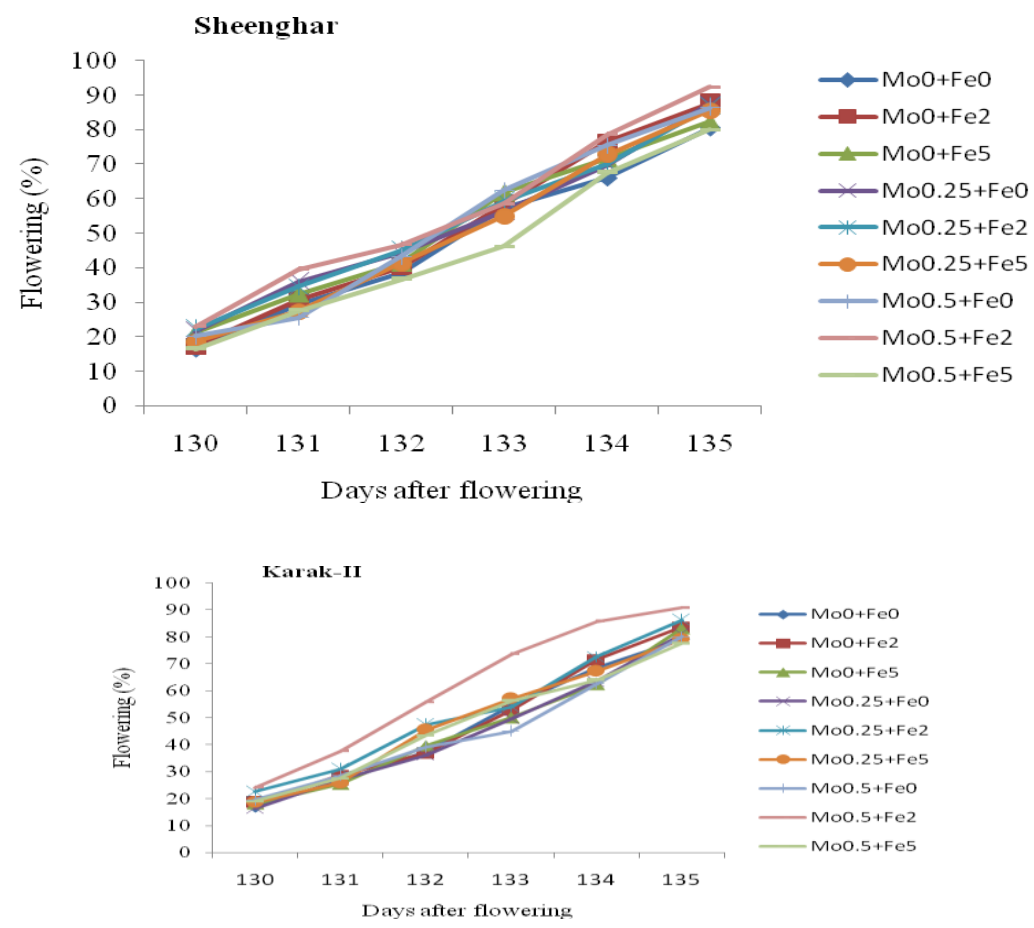

Figure 4.2: Effect of applied molybdenum and iron on the \% flowering of chickpea genotypes

\subsection{Shoot Biomass}

The data regarding shoot biomass is presented in Table 4.3. Results showed that significant differences were found among various molybdenum and iron treatments for shoot biomass of chickpea genotypes. However, maximum shoot biomass 6210 and $6434 \mathrm{~kg} \mathrm{ha}^{-1}$ were found in treatment plot, where Mo 0.5 and Fe 2 $\mathrm{kg} \mathrm{ha}^{-1}$ were applied for both genotypes, while the minimum shoot biomass 4125 and 4375 were recorded in control, (where no molybdenum and iron were applied) in both chickpea genotypes. It showed that both the micronutrients application had positive effect on the production of shoot biomass. The finding results suggested that a normal level molybdenum and iron produced maximum shoot biomass above and below this level the shoot biomass significantly reduced in both chickpea genotypes. Same results were obtained by Sarivestava and Ahlavat (1995). It is observed that the Karak-II genotype yielded more than the Sheenghar genotype of chickpea. Furthermore, beside the poor growth performance of Sheenghar genotype this may also evident from the lower nodules formation and non-significant nitrogen uptake, which directly affected the shoot biomass of chickpea genotype. Sawires (2001) supported our results, who stated that molybdenum, iron and zinc application at $15-30 \mathrm{mg} \mathrm{kg}^{-1}$ increased the straw yield of chickpea.

Table 4.3 Effect of molybdenum and iron application on biomass of chickpea genotypes

\begin{tabular}{|c|c|c|c|c|c|}
\hline \multirow[b]{3}{*}{ Genotypes } & \multirow{3}{*}{$\begin{array}{c}\text { Mo } \\
\left(\mathrm{kg} \mathrm{ha}^{-1}\right)\end{array}$} & \multicolumn{3}{|c|}{ Fe $\left(\mathrm{kg} \mathrm{ha}^{-1}\right)$} & \multirow{3}{*}{$\begin{array}{c}\text { Mean } \\
(\mathrm{V} \times \mathrm{Mo})\end{array}$} \\
\hline & & 0 & 2 & 5 & \\
\hline & & \multicolumn{3}{|c|}{$(\mathrm{V} \times \mathrm{Mo} \times \mathrm{Fe})$} & \\
\hline \multirow[t]{10}{*}{ Sheenghar } & 0 & 4125 & 5215 & 5467 & 4936 \\
\hline & 0.25 & 5735 & 5780 & 5813 & 5776 \\
\hline & 0.5 & 5725 & 6210 & 5825 & 5920 \\
\hline & 0 & 4375 & 5355 & 5800 & 5177 \\
\hline & 0.25 & 5876 & 5890 & 6100 & 5955 \\
\hline & 0.5 & 6125 & 6434 & 6040 & 6200 \\
\hline & & \multicolumn{3}{|c|}{$(\mathrm{Mo} \times \mathrm{Fe})$} & (Mo) \\
\hline & 0 & 4250 & 5285 & 5634 & 5056 \\
\hline & 0.25 & 5806 & 5835 & 5957 & 5866 \\
\hline & 0.5 & 5925 & 6322 & 5933 & 6060 \\
\hline & & \multicolumn{3}{|c|}{$(\mathrm{V} \times \mathrm{Fe})$} & $(\mathrm{V} \times \mathrm{Fe})$ \\
\hline \multirow{2}{*}{\multicolumn{2}{|c|}{$\begin{array}{l}\text { Sheenghar } \\
\text { Karak-II }\end{array}$}} & 5195 & 5735 & 5702 & 5544 \\
\hline & & 5459 & 5893 & 5980 & 5777 \\
\hline \multicolumn{2}{|l|}{ Mean } & 5327 & 5814 & 5841 & \\
\hline
\end{tabular}

LSD value of $\mathrm{P}<0.05$ for $\mathrm{Mo} \times \mathrm{Fe}=80.66$

LSD value of $\mathrm{P}<0.05$ for $\mathrm{Mo}=32.93$ 


\subsection{Grain yield}

The result showed that the different level of the micronutrients (Molybdenum and Iron) significantly increases the yield of chickpea over control Table 4.4. The maximum grain yield of $433 \mathrm{~kg} \mathrm{ha}^{-1}$ and $465 \mathrm{~kg} \mathrm{ha}^{-1}$ were obtained for treatment receiving Mo at 0.5 and Fe at $2 \mathrm{~kg} \mathrm{ha}^{-1}$, while minimum grain yield of $280 \mathrm{~kg} \mathrm{ha}^{-1}$ and $307 \mathrm{~kg} \mathrm{ha}^{-1}$ were obtained in control for both chickpea genotypes. These result suggested that the normal level of micronutrients enhance the grain yield of chickpea above and below this level the grain yield significantly reduced in both chickpea genotypes. Similar observations were found by Sarivestava and Ahlavat (1995) and Sarie et al. (1983). Results showed that genotype Karak-II yielded more than the Sheenghar, this is not only due to the genetic development but it may be due to the environmental conditions, perhaps the environmental conditions were not favorable for Sheenghar genotype, which indicate poor growth performance. Furthermore, beside the poor growth performance of Sheenghar genotype this may be due to the lower nodulation and non-significant nitrogen uptake, which directly affected the total grain yield of chickpea genotype. Results are in line with the previous work of Kothari (2002) and Johansen et al. (2007) who stated that lower nodules formation and nitrogen uptake by legumes consequently reduced grain yield of crops. The application of molybdenum progressively increases the yield of chickpea reported by (Shil et al. 2007). Abd-elGawad et al. (1993) reported positive response of chickpea to phosphorus, molybdenum, iron and zinc. Similarly, Abo-shetaia and Soheir (2001) also observed that the application of phosphorus at $95.2 \mathrm{~kg} \mathrm{ha}^{-1} 47.6-$ $95.2 \mathrm{mg} \mathrm{kg}^{-1} \mathrm{ha}^{-1}$ of micronutrient (molybdenum) significantly increased the number of pods plant ${ }^{-1}$, seed yield and grain yield $\mathrm{kg} \mathrm{ha}^{-1}$ in chickpea (cv.Giza195). The combined application of molybdenum and iron with inoculation gave significantly higher grain yield over control reported by (Singh 2004). Boto et al. (2010) reported that the applications of molybdenum, zinc and boron enhance seed yield mainly due to the number of pods plant ${ }^{-1}$.

Table 4.4 Effect of molybdenum and iron application on the grain yield $\left(\mathrm{kg} \mathrm{ha}^{-1}\right)$ of chickpea genotypes

\begin{tabular}{|c|c|c|c|c|c|}
\hline \multirow[b]{3}{*}{ Genotypes } & \multirow{3}{*}{$\begin{array}{c}\text { Mo } \\
\left(\mathrm{kg} \mathrm{ha}^{-1}\right)\end{array}$} & \multicolumn{3}{|c|}{$\mathrm{Fe}\left(\mathrm{kg} \mathrm{ha}^{-1}\right)$} & \multirow{3}{*}{$\begin{array}{c}\text { Mean } \\
(\mathrm{V} x \mathrm{Mo})\end{array}$} \\
\hline & & 0 & 2 & 5 & \\
\hline & & \multicolumn{3}{|c|}{$(\mathrm{V} \times \mathrm{Mo} \times \mathrm{Fe})$} & \\
\hline \multirow[t]{10}{*}{ Sheenghar } & 0 & 280 & 350 & 300 & 310 \\
\hline & 0.25 & 380 & 366 & 316 & 354 \\
\hline & 0.5 & 416 & 433 & 310 & 386 \\
\hline & 0 & 307 & 344 & 315 & 322 \\
\hline & 0.25 & 400 & 365 & 330 & 365 \\
\hline & 0.5 & 438 & 465 & 345 & 416 \\
\hline & & \multicolumn{3}{|c|}{$(\mathrm{Mo} \times \mathrm{Fe})$} & (Mo) \\
\hline & $\overline{0}$ & 294 & 347 & 308 & 316 \\
\hline & 0.25 & 390 & 366 & 323 & 360 \\
\hline & 0.5 & 427 & 449 & 328 & 401 \\
\hline & & \multicolumn{3}{|c|}{$(\mathrm{V} \times \mathrm{Fe})$} & $(\mathrm{V} \times \mathrm{Fe})$ \\
\hline \multirow{2}{*}{\multicolumn{2}{|c|}{$\begin{array}{l}\text { Sheenghar } \\
\text { Karak-II }\end{array}$}} & 359 & 383 & 309 & 350 \\
\hline & & 382 & 391 & 330 & 368 \\
\hline \multicolumn{2}{|l|}{ Mean } & 370 & 387 & 319 & \\
\hline
\end{tabular}

LSD value of $\mathrm{P}<0.05$ for $\mathrm{Mo}=29.61$

LSD value of $\mathrm{P}<0.05$ for $\mathrm{Mo} \times \mathrm{Fe}=51.29$

\subsection{Pods plant ${ }^{-1}$}

The data regarding number of pods plant ${ }^{-1}$ is presented in Table 4.5. Results showed that significant differences were found among various molybdenum and iron treatments for number of pods plant ${ }^{-1}$. However, more pods (32) and (33) were found in the treatment plot, where Mo 0.5 and Fe $2 \mathrm{~kg} \mathrm{ha}^{-1}$ were applied for both genotypes and less pods plant ${ }^{-1}$ were recorded in control. Srivastava and Ahlawat (1995) and Rabbani et al. (2005) also observed positive effect of molybdenum and reported that applied molybdenum gave statistically significance effect on the average number of pods plant ${ }^{-1}$. Similarly, Boto et al. (2010) reported that the application of molybdenum, zinc and boron enhance the number of pods plant ${ }^{-1}$. Results further showed that the performance of genotype Karak-II was found better than the Sheenghar in terms of pods plant ${ }^{-1}$, suggested Karak-II is more productive which gave higher yield than Sheenghar under the conditions of the experiment. 
Table 4.5 Effect of molybdenum and iron application on pods plant ${ }^{-1}$ of chickpea genotypes

\begin{tabular}{|c|c|c|c|c|c|}
\hline \multirow[b]{3}{*}{ Genotypes } & \multirow{3}{*}{$\begin{array}{c}\text { Mo } \\
\left(\mathrm{kg} \mathrm{ha}^{-1}\right)\end{array}$} & \multicolumn{3}{|c|}{$\mathrm{Fe}\left(\mathrm{kg} \mathrm{ha}^{-1}\right)$} & \multirow{3}{*}{$\begin{array}{c}\text { Mean } \\
(\mathrm{V} x \mathrm{Mo})\end{array}$} \\
\hline & & 0 & 2 & 5 & \\
\hline & & \multicolumn{3}{|c|}{$(\mathrm{V} \times \mathrm{Mo} \times \mathrm{Fe})$} & \\
\hline \multirow[t]{10}{*}{ Sheenghar } & 0 & 27 & 23 & 16 & 22 \\
\hline & 0.25 & 28 & 29 & 33 & 30 \\
\hline & 0.5 & 28 & 32 & 25 & 28 \\
\hline & 0 & 20 & 23 & 18 & 20 \\
\hline & 0.25 & 21 & 23 & 31 & 25 \\
\hline & 0.5 & 28 & 33 & 22 & 28 \\
\hline & & \multicolumn{3}{|c|}{$(\mathrm{Mo} \times \mathrm{Fe})$} & (Mo) \\
\hline & $\overline{0}$ & 24 & 23 & 17 & 21 \\
\hline & 0.25 & 25 & 26 & 32 & 28 \\
\hline & 0.5 & 28 & 33 & 24 & 26 \\
\hline & & \multicolumn{3}{|c|}{$(\mathrm{V} \times \mathrm{Fe})$} & $(\mathrm{V} \times \mathrm{Fe})$ \\
\hline \multirow{2}{*}{\multicolumn{2}{|c|}{$\begin{array}{l}\text { Sheenghar } \\
\text { Karak-II }\end{array}$}} & 28 & 25 & 25 & 26 \\
\hline & & 23 & 26 & 24 & 24 \\
\hline \multicolumn{2}{|l|}{ Mean } & 25 & 26 & 25 & \\
\hline
\end{tabular}

LSD value of $\mathrm{P}<0.05$ for $\mathrm{Mo}=1.66$

LSD value of $\mathrm{P}<0.05$ for $\mathrm{Mo} \times \mathrm{Fe}=2.88$

\subsection{Seeds pod ${ }^{-1}$}

The data observed on number of seeds $\operatorname{pod}^{-1}$ are given in Table 4.6. Non significant differences were observed among various molybdenum and iron treatments for number of seeds $\operatorname{pod}^{-1}$. However, maximum seeds $\operatorname{pod}^{-1}(1.6)$ and (1.7) were found in treatment plot where Mo 0.5 and Fe $2 \mathrm{~kg} \mathrm{ha}^{-1}$ were applied for both chickpea genotypes and minimum seed $\operatorname{pod}^{-1}(1.3)$ and (1.0) were recorded in control, (where no molybdenum and no iron were applied). The increase in number of seeds pod $^{-1}$ by the application of molybdenum along with iron may be due to the fact that molybdenum and iron may fixed that much amount of nitrogen which was required by the plant to show better performance as molybdenum is related directly to nitrogen fixation by legumes. Result also showed that the molybdenum and iron nutrition had similar effect on both chickpea genotypes. Similar observations were found by Landge et al. (2002) and Tahir et al. (2011).

Table 4.6Effect of molybdenum and iron application on seeds pod $^{-1}$ of chickpea genotypes

\begin{tabular}{|c|c|c|c|c|c|}
\hline \multirow[b]{3}{*}{ Genotypes } & \multirow{3}{*}{$\begin{array}{c}\text { Mo } \\
\left(\mathrm{kg} \mathrm{ha}^{-1}\right)\end{array}$} & \multicolumn{3}{|c|}{$\mathrm{Fe}\left(\mathrm{kg} \mathrm{ha}^{-1}\right)$} & \multirow{3}{*}{$\begin{array}{c}\text { Mean } \\
(\mathrm{V} x \mathrm{Mo})\end{array}$} \\
\hline & & 0 & 2 & 5 & \\
\hline & & \multicolumn{3}{|c|}{$(\mathrm{V} x \mathrm{Mo}$ x Fe) } & \\
\hline \multirow[t]{10}{*}{ Sheenghar } & 0 & 1.3 & 1.4 & 1.6 & 1.4 \\
\hline & 0.25 & 1.5 & 1.4 & 1.4 & 1.4 \\
\hline & 0.5 & 1.5 & 1.6 & 1.3 & 1.5 \\
\hline & 0 & 1.0 & 1.4 & 1.2 & 1.2 \\
\hline & 0.25 & 1.5 & 1.3 & 1.3 & 1.4 \\
\hline & 0.5 & 1.4 & 1.7 & 1.4 & 1.5 \\
\hline & & \multicolumn{3}{|c|}{$(\mathrm{Mo} \times \mathrm{Fe})$} & (Mo) \\
\hline & 0 & 1.2 & 1.4 & 1.4 & 1.3 \\
\hline & 0.25 & 1.5 & 1.4 & 1.4 & 1.4 \\
\hline & 0.5 & 1.5 & 1.7 & 1.4 & 1.5 \\
\hline & & \multicolumn{3}{|c|}{$(\mathrm{V} \times \mathrm{Fe})$} & $(\mathrm{V} \times \mathrm{Fe})$ \\
\hline \multirow{2}{*}{\multicolumn{2}{|c|}{$\begin{array}{l}\text { Sheenghar } \\
\text { Karak-II }\end{array}$}} & 1.4 & 1.5 & 1.4 & 1.4 \\
\hline & & 1.3 & 1.5 & 1.3 & 1.4 \\
\hline \multicolumn{2}{|l|}{ Mean } & 1.4 & 1.5 & 1.4 & \\
\hline
\end{tabular}

LSD value of $\mathrm{P}<0.05$ for $\mathrm{Mo}=0.42$ 


\subsection{0 seeds weight}

Data regarding that 100 -seed weight was significantly affected by the application of molybdenum and iron presented in Table 4.7. The maximum 100-seed weight $17.30 \mathrm{~g}$ was obtained in treatment plot, where Mo 0.5 and Fe $2 \mathrm{~kg} \mathrm{ha}^{-1}$ were applied in genotype Sheenghar and $22.2 \mathrm{~g}$ was obtained in Karak-II where Mo 0.5 and $\mathrm{Fe} 2 \mathrm{~kg} \mathrm{ha}^{-1}$ were used as treatment. While, the minimum 100- seed weight 16.75 and $22.03 \mathrm{~g}$ were observed in control treatment for both chickpea genotypes. Rabbani et al. (2005) found that the application of Rhizobium inoculant in combination with phosphorus and molybdenum gave statistically significant 100 -seed weight. These results indicated that nil or excess molybdenum and iron reduced the 100-seed weight as compared to those plots which received normal levels of molybdenum and iron. These results are supported by previous work of Kevresan et al. (2001). Moreover, Nautiyal et al. (2005) stated that leguminous plants are very sensitive to molybdenum effects, but excess molybdenum may impair growth and decrease the seed yield of the crops. In the present experiment excess molybdenum reduced the seed yield of both chickpea genotypes. Results also showed that the seeds of Kabuli genotype (Karak-II) were heavier than the Desi genotype (Sheenghar), perhaps this may be due to genetic difference not due to nutritional effect.

Table 4.7 Effect of molybdenum and iron application on 100 seeds weight (g) of chickpea genotypes

\begin{tabular}{|c|c|c|c|c|c|}
\hline \multirow[b]{3}{*}{ Genotypes } & \multirow{3}{*}{$\begin{array}{c}\text { Mo } \\
\left(\mathrm{kg} \mathrm{ha}^{-1}\right)\end{array}$} & \multicolumn{3}{|c|}{$\mathrm{Fe}\left(\mathrm{kg} \mathrm{ha}^{-1}\right)$} & \multirow{3}{*}{$\begin{array}{c}\text { Mean } \\
(\mathrm{V} x \mathrm{Mo})\end{array}$} \\
\hline & & 0 & 2 & 5 & \\
\hline & & \multicolumn{3}{|c|}{$(\mathrm{V} x \mathrm{Mo} \times \mathrm{Fe})$} & \\
\hline \multirow{10}{*}{ Karak-II } & 0 & 16.8 & 17.2 & 17.2 & 17.1 \\
\hline & 0.25 & 17.3 & 17.3 & 17.3 & 17.3 \\
\hline & 0.5 & 17.3 & 17.3 & 17.3 & 17.3 \\
\hline & 0 & 22.0 & 22.2 & 22.2 & 22.1 \\
\hline & 0.25 & 22.2 & 22.1 & 22.1 & 22.1 \\
\hline & 0.5 & 22.0 & 22.2 & 22.1 & 22.1 \\
\hline & & \multicolumn{3}{|c|}{$(\mathrm{Mo} \times \mathrm{Fe})$} & (Mo) \\
\hline & 0 & 19.4 & 19.7 & 19.7 & 19.6 \\
\hline & 0.25 & 19.7 & 19.7 & 19.7 & 19.7 \\
\hline & 0.5 & 19.7 & 19.7 & 19.7 & 19.7 \\
\hline & & \multicolumn{3}{|c|}{$(\mathrm{V} \times \mathrm{Fe})$} & $(\mathrm{V} x \mathrm{Fe})$ \\
\hline \multirow{2}{*}{\multicolumn{2}{|c|}{$\begin{array}{l}\text { Sheenghar } \\
\text { Karak-II }\end{array}$}} & 17.0 & 17.1 & 17.3 & 17.3 \\
\hline & & 22.0 & 22.1 & 22.1 & 22.1 \\
\hline \multicolumn{2}{|l|}{ Mean } & 19.3 & 19.6 & 19.7 & 19.7 \\
\hline
\end{tabular}

LSD value of $\mathrm{P}<0.05$ for $\mathrm{Mo}=8.783$

\subsection{Fresh weight of nodules}

The data obtained on fresh weight of nodules plant ${ }^{-1}$ are presented in Table 4. 8. Highly significant differences were observed among the different molybdenum and iron treatments. The maximum fresh weight of nodules $3.13 \mathrm{~g}$ and $2.84 \mathrm{~g}$ were obtained in the treatment plots, where Mo 0.5 and $\mathrm{Fe} 2 \mathrm{~kg} \mathrm{ha}^{-1}$ were applied for both chickpea genotypes, while minimum fresh weight of nodules $1.45 \mathrm{~g}$ and $1.59 \mathrm{~g}$ were recorded in the treatment plots, where Mo 0 and Fe $5 \mathrm{~kg} \mathrm{ha}^{-1}$ were applied respectively. These results indicated that fresh weight of nodules was affected by the nutrition of molybdenum and iron application. Bhanavase and Patil (1994) reported that molybdenum enhance nodule numbers, nodule weight plant $^{-1}$ and nitrogen concentration of nodules.

Table 4.8 Effect of molybdenum and iron application on nodules fresh weight (g) of chickpea genotypes

\begin{tabular}{|c|c|c|c|c|c|}
\hline \multirow[b]{3}{*}{ Genotypes } & \multirow{3}{*}{$\begin{array}{c}\text { Mo } \\
\left(\mathrm{kg} \mathrm{ha}^{-1}\right)\end{array}$} & \multicolumn{3}{|c|}{$\mathrm{Fe}\left(\mathrm{kg} \mathrm{ha}^{-1}\right)$} & \multirow{3}{*}{$\begin{array}{c}\text { Mean } \\
(\mathrm{V} x \mathrm{Mo})\end{array}$} \\
\hline & & 0 & 2 & 5 & \\
\hline & & \multicolumn{3}{|c|}{$(\mathrm{V} \times \mathrm{Mo} \times \mathrm{Fe})$} & \\
\hline \multirow[t]{6}{*}{ Sheenghar } & 0 & 2.0 & 1.7 & 1.6 & 1.8 \\
\hline & 0.25 & 2.3 & 2.5 & 2.4 & 2.4 \\
\hline & 0.5 & 2.6 & 2.8 & 2.6 & 2.7 \\
\hline & 0 & 1.7 & 1.8 & 1.5 & 1.6 \\
\hline & 0.25 & 2.2 & 2.7 & 2.6 & 2.5 \\
\hline & 0.5 & 2.9 & 3.1 & 2.7 & 2.9 \\
\hline & & \multicolumn{3}{|c|}{$(\mathrm{Mo} \times \mathrm{Fe})$} & (Mo) \\
\hline
\end{tabular}




\begin{tabular}{|c|c|c|c|c|c|}
\hline & $\begin{array}{c}0 \\
0.25 \\
0.5 \\
\end{array}$ & $\begin{array}{l}1.8 \\
2.2 \\
2.8 \\
\end{array}$ & $\begin{array}{l}1.7 \\
2.6 \\
3.0 \\
\end{array}$ & $\begin{array}{l}1.5 \\
2.5 \\
2.6 \\
\end{array}$ & $\begin{array}{l}1.7 \\
2.4 \\
2.8 \\
\end{array}$ \\
\hline & & \multicolumn{3}{|c|}{$(\mathrm{V} \times \mathrm{Fe})$} & $(\mathrm{V} \times \mathrm{Fe})$ \\
\hline Sheenghar & & 2.3 & 2.3 & 2.2 & 2.3 \\
\hline Karak-II & & 2.3 & 2.5 & 2.2 & 2.3 \\
\hline Mean & & 2.3 & 2.4 & 2.2 & \\
\hline
\end{tabular}

LSD value of $\mathrm{P}<0.05$ for $\mathrm{Mo}=0.06$

\subsection{Effect on nodulation}

The results obtained on number of nodules in chickpea genotypes are presented and discussed below:

\section{Number of nodules}

The data obtained on numbers of nodules plant ${ }^{-1}$ at flowering stage are presented in Table 4.9. It has a direct effect on the grain yield of chickpea genotypes. The data showed that molybdenum highly significantly and iron significantly affected the number of nodules plant ${ }^{-1}$ in chickpea compared with control. The maximum nodules of 49 and 54 were obtained for treatment receiving Mo at 0.5 and $\mathrm{Fe}$ at $2 \mathrm{~kg} \mathrm{ha}^{-1}$, in both chickpea genotypes, while the minimum nodules of 28 and 25 were obtained for treatment receiving Mo at 0 and $\mathrm{Fe}$ at 5 $\mathrm{kg} \mathrm{ha}^{-1}$ in both chickpea genotypes. The result suggested that molybdenum generally enhanced the number of nodules in chickpea genotypes. Bhanavase and Patil (1994) reported that molybdenum increased nodule numbers, nodule weight plant ${ }^{-1}$ and nitrogen concentration of nodules. Verma et al. (1988) observed in their pot experiment that molybdenum at $0.5-2 \mathrm{mg} \mathrm{kg}^{-1}$ increases the number of nodules in chickpea (cv. Radhey). Moreover, in the present study the number of nodules were regressed with nitrogen content of plants for both genotypes (Figure 4.3) and observed as the formation of nodules increases the nitrogen content of plant linearly increased. Generally Karak-II genotype showed maximum nodulation and maximum nitrogen uptake compared to Sheenghar genotype, but the $\mathrm{r}^{2}$ value $\left(\mathrm{r}^{2}=0.224\right)$ was slightly lower than Karak-II genotype $\left(\mathrm{r}^{2}=0.366\right)$. These results suggest that the Sheenghar genotype utilized more nitrogen than Karak-II genotype. Cutcliffe (1986) and Brkics et al. (2004) observed same correlation between nodules and plant nitrogen in legumes, who reported that as the nodulation increases the nitrogen content in plants increased and consequently the grain yield increased.

Table 4.9 Effect of molybdenum and iron application on nodules plant $^{-1}$ of chickpea genotypes

\begin{tabular}{|c|c|c|c|c|c|}
\hline \multirow[b]{3}{*}{ Genotypes } & \multirow{3}{*}{$\begin{array}{c}\text { Mo } \\
\left(\mathrm{kg} \mathrm{ha}^{-1}\right)\end{array}$} & \multicolumn{3}{|c|}{$\mathrm{Fe}\left(\mathrm{kg} \mathrm{ha}^{-1}\right)$} & \multirow{3}{*}{$\begin{array}{c}\text { Mean } \\
(\mathrm{V} x \mathrm{Mo})\end{array}$} \\
\hline & & 0 & 2 & 5 & \\
\hline & & \multicolumn{3}{|c|}{$(\mathrm{V} \times \mathrm{Mo} \times \mathrm{Fe})$} & \\
\hline \multirow[t]{10}{*}{ Sheenghar } & 0 & 35 & 30 & 28 & 31 \\
\hline & 0.25 & 40 & 43 & 41 & 41 \\
\hline & 0.5 & 46 & 49 & 44 & 46 \\
\hline & 0 & 30 & 31 & 25 & 29 \\
\hline & 0.25 & 38 & 47 & 45 & 43 \\
\hline & 0.5 & 50 & 54 & 48 & 51 \\
\hline & & \multicolumn{3}{|c|}{$(\mathrm{Mo} \times \mathrm{Fe})$} & (Mo) \\
\hline & 0 & 33 & 31 & 27 & 30 \\
\hline & 0.25 & 39 & 45 & 43 & 42 \\
\hline & 0.5 & 48 & 52 & 46 & 49 \\
\hline & & \multicolumn{3}{|c|}{$(\mathrm{V} \times \mathrm{Fe})$} & $(\mathrm{V} \times \mathrm{Fe})$ \\
\hline \multirow{2}{*}{\multicolumn{2}{|c|}{$\begin{array}{l}\text { Sheenghar } \\
\text { Karak-II }\end{array}$}} & 40 & 40 & 41 & 38 \\
\hline & & 39 & 39 & 44 & 39 \\
\hline \multicolumn{2}{|l|}{ Mean } & 40 & 40 & 42 & 39 \\
\hline
\end{tabular}

LSD value of $\mathrm{P}<0.05$ for $\mathrm{Mo}=3.21$

LSD value of $\mathrm{P}<0.05$ for $\mathrm{Fe}=3.21$ 

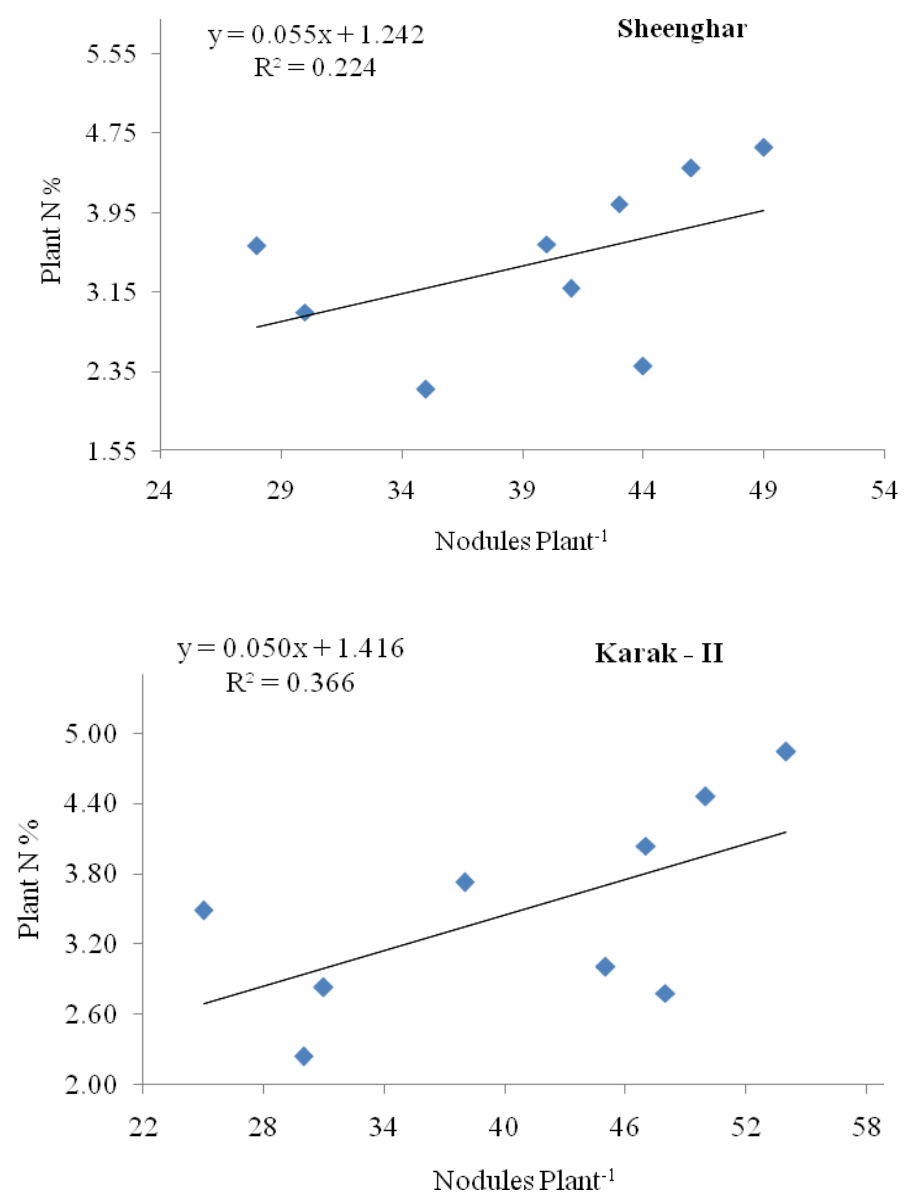

Figure 4.3 Relationship between nodulation and plant $N \%$ in chickpea genotypes

\subsection{Nutrient contents in plant leaves}

\subsubsection{N concentration}

At flowering stage plant leaves were analyzed for nitrogen concentration, to obtain that how much nitrogen concentration fixed by plant, which can be used for sowing in the subsequent season. The data obtained on the nitrogen concentration in shoot at maximum biomass stage of chickpea is presented in Table 4.10. Significant differences were found among the different treatments of molybdenum and iron for nitrogen concentration. The maximum nitrogen concentration of $4.60 \%$ and $4.84 \%$ in shoot biomass of chickpea genotypes were obtained for treatment receiving Mo at 0.5 and $\mathrm{Fe}$ at $2 \mathrm{~kg} \mathrm{ha}^{-1}$ respectively. While, the minimum nitrogen concentration $2.18 \%$ and $2.24 \%$ were obtained for control, (where no molybdenum and iron were applied) in both genotypes of chickpea. The data showed that no treatment plot was found N-deficient for both chickpea genotypes as the threshold values reported by Westermann (2005) and Kaiser et al. (2005). This is good evidence that the leaves of chickpea plant still contain sufficient nitrogen because an adequate amount of nutrient is required for seed germination. Bhanavase and Patil (1994) reported that molybdenum enhance nodule numbers, nodule weight plant ${ }^{-1}$ and nitrogen concentration of nodules. Results further showed that significant differences were found in nitrogen contents for both genotypes and both genotypes increases nitrogen concentration in a similar fashion as the iron concentration increases in plant leaves, suggested iron played a key role in nitrogen fixation by chickpea genotypes. The previous work of Marschner (1995) and Vieira et al. (1998) support our result. Furthermore, in the present study plant iron were regressed with nitrogen for both chickpea genotypes (Figure 4.5) and observed as the plant-Fe increases the N-concentration in plants linearly increased. However, the correlation of the Karak-II genotype as compared to Sheenghar genotype could not attain statistical significance because of little variation in Fe-content of chickpea leaves. Westermann (2005) and Kaiser et al. (2005) observed same relationship between plant iron and nitrogen, who stated that iron played a vital role in the nitrogen fixation by legumes. 
Table 4.10 Effect of molybdenum and iron application on $N$ concentration $(\%)$ of chickpea genotypes

\begin{tabular}{|c|c|c|c|c|c|}
\hline \multirow[b]{3}{*}{ Genotypes } & \multirow{3}{*}{$\begin{array}{c}\text { Mo } \\
\left(\mathrm{kg} \mathrm{ha}^{-1}\right)\end{array}$} & \multicolumn{3}{|c|}{$\mathrm{Fe}\left(\mathrm{kg} \mathrm{ha}^{-1}\right)$} & \multirow{3}{*}{$\begin{array}{c}\text { Mean } \\
(\mathrm{V} \times \mathrm{Mo})\end{array}$} \\
\hline & & 0 & 2 & 5 & \\
\hline & & \multicolumn{3}{|c|}{$(\mathrm{V} \times \mathrm{Mo} \times \mathrm{Fe})$} & \\
\hline \multirow{10}{*}{ Karak-II } & 0 & 2.18 & 2.95 & 3.61 & 2.91 \\
\hline & 0.25 & 3.63 & 4.04 & 3.19 & 3.62 \\
\hline & 0.5 & 4.40 & 4.61 & 2.41 & 3.81 \\
\hline & 0 & 2.24 & 2.83 & 3.49 & 2.85 \\
\hline & 0.25 & 3.72 & 4.04 & 3.00 & 3.59 \\
\hline & 0.5 & 4.46 & 4.84 & 2.78 & 4.03 \\
\hline & & \multicolumn{3}{|c|}{$(\mathrm{Mo} \times \mathrm{Fe})$} & (Mo) \\
\hline & 0 & 2.21 & 2.89 & 3.55 & 2.88 \\
\hline & 0.25 & 3.68 & 4.04 & 3.10 & 3.60 \\
\hline & 0.5 & 4.43 & 4.73 & 2.60 & 3.92 \\
\hline & & \multicolumn{3}{|c|}{$(\mathrm{V} \times \mathrm{Fe})$} & $(\mathrm{V} \times \mathrm{Fe})$ \\
\hline Sheenghar & & 3.40 & 3.87 & 3.07 & 3.07 \\
\hline Karak-II & & 3.47 & 3.90 & 3.09 & 3.09 \\
\hline Mean & & 3.44 & 3.89 & 3.08 & 3.08 \\
\hline
\end{tabular}

LSD value of $\mathrm{P}<0.05$ for $\mathrm{Fe}=0.48$

LSD value of $\mathrm{P}<0.05$ for $\mathrm{Mo}=2.77$

LSD value of $\mathrm{P}<0.05$ for Fe $\mathrm{x}$ Genotypes $=0.83$

\subsubsection{Iron concentration}

The data obtained on iron concentration in shoot at maximum biomass of chickpea is presented in Table 4.12. Significant differences were observed among the different treatments of molybdenum and iron. In both genotypes the maximum iron concentration was obtained for the treatment which receiving Mo at 0.5 and $\mathrm{Fe}$ at $2 \mathrm{~kg} \mathrm{ha}^{-1}$ which is $248 \mu \mathrm{g} \mathrm{g}^{-1}$ in Sheenghar and $276 \mu \mathrm{g} \mathrm{g}^{-1}$ in Karak-II genotype respectively. While, the minimum iron concentration was $110 \mu \mathrm{g} \mathrm{g}^{-1}$ and $156 \mu \mathrm{g} \mathrm{g}^{-1}$ were observed in control, (where no molybdenum and iron were applied) in both chickpea genotypes. The iron concentration in plant leaves significantly increased with increasing levels of applied iron and molybdenum in both chickpea genotypes. Results showed that with increasing the levels of molybdenum and iron fertilizers the concentration of iron in plant leaves were also increased may be due to positive interaction between iron and molybdenum within legume plants. Moreover, these results showed that no treatment plot was found Fe-deficient for both chickpea genotypes, as the threshold values suggested by Katyal and Randhawa (1982).

Table 4.12 Effect of molybdenum and iron application on $\mathrm{Fe}\left(\mu \mathrm{g} \mathrm{g}^{-1}\right)$ concentration by chickpea genotypes

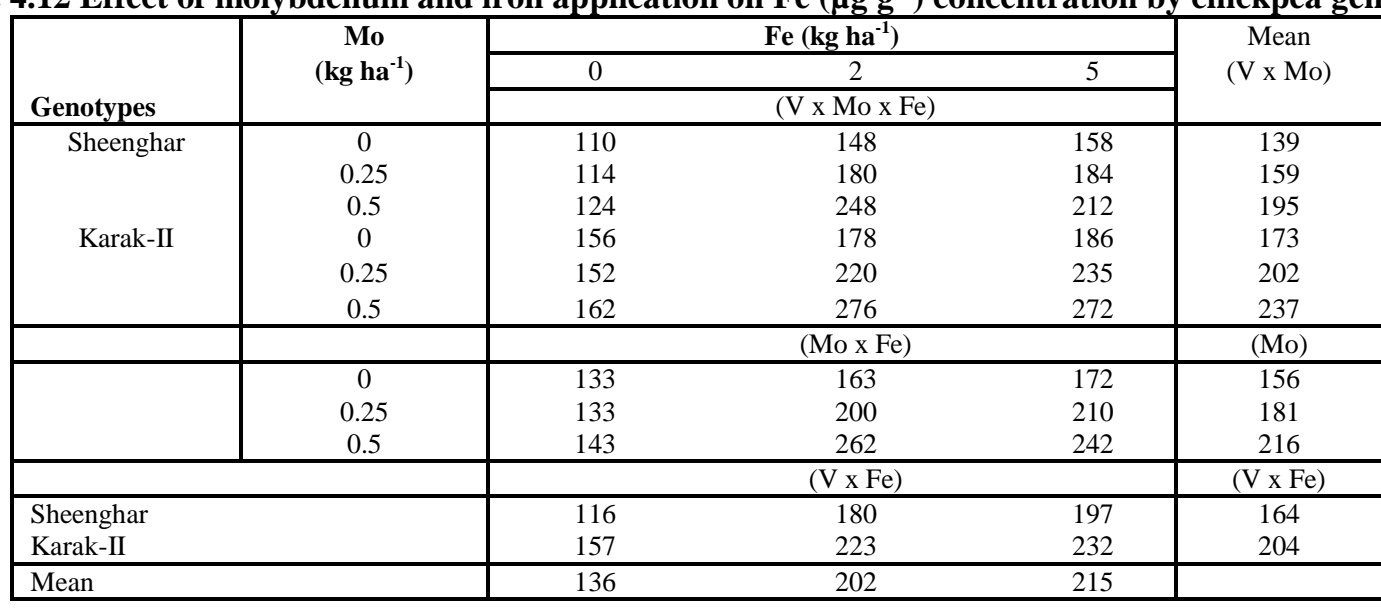

LSD value of $\mathrm{P}<0.05$ for Mo 20.57 
LSD value of $\mathrm{P}<0.05$ for $\mathrm{Fe}=20.57$

LSD value of $\mathrm{P}<0.05$ for $\mathrm{Mo} \times \mathrm{Fe}=35.63$

\section{Summary}

A field experiment was conducted at Malakandher Farm, The University of Agriculture Peshawar, during November, 2011 to study the effect of molybdenum and iron on the nodulation, nitrogen fixation and yield of two chickpea genotypes, such as Desi (genotype Sheenghar) and Kabuli (genotype Karak-II). The chickpea seeds were sown in randomized complete block design with split plot arrangement and replicated 3 times. A plot size was kept $6 \mathrm{~m}^{2}$. Each plot was comprised of 3 rows containing row to row distance of $30 \mathrm{~cm}$ apart and plant to plant distance was of $20 \mathrm{~cm}$. Different levels of molybdenum at the rate of $0,0.25$ and 0.5 and iron at the rate of 0,2 and $5 \mathrm{~kg} \mathrm{ha}^{-1}$ was applied in the form of ammonium molybdate and iron sulfate, respectively. A basal dose of $25 \mathrm{~N}, 60 \mathrm{P}_{2} \mathrm{O}_{5}$ and $60 \mathrm{~K}_{2} \mathrm{O} \mathrm{kg} \mathrm{ha}{ }^{-1}$ was applied in the form of urea, di ammonium phosphate and potassium sulfate, respectively before sowing. Before fertilizer application a composite soil sample was collected for the determination of physico-chemical characteristics and desired nutrients status of the test soil. All culture practices were performed when required.

Results showed that the maximum emergence and flowering were recorded in treatment plots where Mo 0.5 and $\mathrm{Fe} 2 \mathrm{~kg} \mathrm{ha}^{-1}$ were applied for both chickpea genotypes. While, the minimum emergence and flowering was observed in those plots which received Mo 0 and Fe $0 \mathrm{~kg} \mathrm{ha}^{-1}$. Days to emergence and days to flowering data also showed that the emergence rate and number of flowering in molybdenum and iron plots were comparatively better than control plots. Moreover, results revealed that the different treatments of molybdenum and iron varied significantly regarded to days to emergence and number of days to flowering. Results also showed that significant differences were found among various molybdenum and iron treatments for number of pods plant ${ }^{-1}$ and seed pod ${ }^{-1}$. However, more pods and seeds were found in treatment plot, where Mo 0.5 and $\mathrm{Fe} 2 \mathrm{~kg} \mathrm{ha}^{-1}$ were applied for both genotypes and less pods plant ${ }^{-1}$ and seed pod ${ }^{-1}$ were recorded in treatment plot, where Mo 0 and $\mathrm{Fe} 2 \mathrm{~kg} \mathrm{ha}^{-1}$ were applied. Results further showed that the performance of Karak-II genotype was found better than the Sheenghar genotype in terms of pods plant ${ }^{-1}$ and seed pod ${ }^{-1}$ and suggested Karak-II genotype is more productive which gave higher yield than Sheenghar genotype under the conditions of the experiment. Results also showed that in general, the seeds of Karak-II genotype were heavier than the Sheenghar genotype of chickpea. Number of nodules has a direct effect on the grain yield of chickpea genotypes. The data showed that molybdenum and iron significantly affected the number of nodules plant ${ }^{-1}$ and seed yield of chickpea compared to control. The maximum number of nodules plant ${ }^{-1}$ and seed yield was obtained for treatment receiving $\mathrm{Mo}$ at 0.5 and $\mathrm{Fe}$ at $2 \mathrm{~kg} \mathrm{ha}^{-1}$ in both chickpea genotypes. These results suggested that both micronutrients enhanced the grain yield of chickpea genotypes. The present results suggested that molybdenum has a positive effect on nodules formation in legume genotypes, because Modeficient plants result decreased number of nodules and seed yield compared to plots of molybdenum applied to chickpea genotypes. Generally Kabuli genotype (Karak-II) showed maximum nodulation and maximum nitrogen uptake compared to Sheenghar genotype, but the $r^{2}$ value $\left(r^{2}=0.22\right)$ was slightly lower than Kabuli genotype $\left(\right.$ Karak-II) $\left(\mathrm{r}^{2}=0.37\right)$. These results suggest that Desi genotype (Sheenghar) utilized more nitrogen than (Karak-II) genotype. Results showed that significant differences were found among various molybdenum and iron treatments for shoot biomass of chickpea genotypes. However, maximum shoot biomass were found in treatment plot, where Mo 0.5 and Fe $2 \mathrm{~kg} \mathrm{ha}^{-1}$ were applied for both genotypes, while the minimum shoot biomass were recorded in control (where no molybdenum and iron) were applied for both chickpea genotypes. It showed that both the micronutrients applications have positive effect on the production of shoot biomass.

The maximum nitrogen content and uptake was obtained for treatment receiving Mo at 0.5 and $\mathrm{Fe}$ at $2 \mathrm{~kg}$ $\mathrm{ha}^{-1}$ for both chickpea genotypes. The results suggested that both Mo and Fe increased the nitrogen concentration in shoot of chickpea genotypes. Results further showed that the differences found in nitrogen contents for both genotypes were not very large and both genotypes increases nitrogen concentration. Iron played a key role in nitrogen fixation by chickpea genotypes. In both genotypes the maximum iron concentration and uptake were obtained for the same treatment which receiving Mo at 0.5 and $\mathrm{Fe}$ at $2 \mathrm{~kg} \mathrm{ha}^{-1}$. Generally Kabuli genotype (Karak-II) showed maximum iron and nitrogen uptake compared to Desi genotype (Sheenghar), the $\mathrm{r}^{2}$ value $\left(\mathrm{r}^{2}=0.10\right)$ was slightly lower than Kabuli genotype (Karak-II) $\left(\mathrm{r}^{2}=0.22\right)$. These results suggest that the Kabuli genotype (Karak-II) utilized more iron than Desi genotype (Sheenghar).

Based on the present findings it is recommend that the application of molybdenum at $0.5 \mathrm{~kg} \mathrm{ha}^{-1}$ and iron at $2 \mathrm{~kg} \mathrm{ha}^{-1}$ to chickpea genotypes for better growth performance, more nodulations and adequate nitrogen uptake by legume genotypes. 


\section{Conclusion}

The following conclusions could be drawn from this study.

* Days to emergence and days to flowering were not significantly affected by the application of molybdenum and iron for both genotypes of chickpea. However, maximum emergence and flowering were recorded in treatment plots where Mo 0.5 and Fe $2 \mathrm{~kg} \mathrm{ha}^{-1}$ were applied for both chickpea genotypes.

* The grain yield was significantly increased with application of Mo at 0.5 and $\mathrm{Fe}$ at $2 \mathrm{~kg} \mathrm{ha}^{-1}$ for both chickpea genotypes Desi (Sheenghar) and Kabuli (Karak-II). It was also noted that Kabuli genotype (Karak-II) yielded greater than Desi genotype (Sheenghar).

* Maximum numbers of nodules were obtained in the treatment plots, where Mo 0.5 and Fe $2 \mathrm{~kg} \mathrm{ha}^{-1}$ were applied for both chickpea genotypes. Generally Kabuli genotype (Karak-II) showed more nodulation and more N-uptake compared to Desi genotype (Sheenghar). These results suggest that the Karak-II genotype utilized more nitrogen than Sheenghar genotype.

* At flowering stage, nitrogen concentration in leaves increased with increasing levels of Mo and Fe in soil in both genotypes, and the differences found in nitrogen contents for both genotypes were not very large and both genotypes increases nitrogen concentration in a similar fashion, suggested iron played a vital role in nitrogen fixation by chickpea genotypes.

* Similarly, the concentration of iron in leaves significantly increased with increasing levels of applied molybdenum and iron in both genotypes of chickpea. Generally, the concentration of iron was found more in chickpea genotype Karak-II than Sheenghar, indicating Karak-II genotype was more efficient than Sheenghar in absorbing the iron nutrition.

* The number of nodules were correlated with nitrogen content of plants for both genotypes and found as the nodules formation increases the plant nitrogen concentration linearly increased and showed close relationship with one another. Similarly, the iron uptake increases in plant leaves, nitrogen uptake also increases, indicated that iron played a vital role in nitrogen fixation by chickpea genotypes.

* The overall results suggested that Kabuli genotype (Karak-II) had the maximum grain yield, number of nodules and nitrogen uptake as compared to Desi genotype (Sheenghar) with the application of Mo 0.5 and $\mathrm{Fe} 2 \mathrm{~kg} \mathrm{ha}^{-1}$ under the prevailing conditions of the experiment.

\section{Recommendation}

The following recommendations were formulated from the present study.

* Presently $0.5 \mathrm{~kg} \mathrm{ha}^{-1} \mathrm{Mo}$ and $2 \mathrm{~kg} \mathrm{ha}^{-1} \mathrm{Fe}$ is suggested for getting maximum yield, nodulation and nitrogen fixation by chickpea genotypes under the prevailing conditions.

* The suggested levels of molybdenum and iron for maximum yield, nodulation and nitrogen fixation need to be studied on different chickpea genotypes under different ecological conditions of the Khyber Pakhtoon Khwa Province.

\section{Literature Cited}

[1]. Abd. El. Gawad, A.A., D.M. El.Hariri, A.M.A. Abo-Shetaia, and A.A. Bahr. 1993. Yield and yield components responses of chickpea (Cicer arietinum L.) to phosphorus fertilization and micronutrients. Afri. J. Agri. Sci. 18: 61-71.

[2]. Abo-Shetaia,. A. M., and A.M. Soheir. 2001 Yield and yield components responses of chickpea (Cicer arietinum L.) to phosphorus fertilization and micronutrients. Arab Univ. J. Agric. Sci. 9: 235-243.

[3]. Ali, M., J.P. Mishera, and M. Ali. 2000. Nutrients management in pulses and pulse-based cropping system. Fert. News. 45: 57-69.

[4]. Anderson, A. J. and D. Spencer. 1999. Molybdenum and sulphur in symbiotic nitrogen fixation. Bioch.and Biophy. Res. Commun.164:273-274

[5]. Bambara, S. and P. A. Ndakidemi. 2010. The potential roles of lime and molybdenum on the growth, nitrogen fixation and assimilation of metabolites in nodulated legume: A special reference to Phaseolus vulgaris L. African. J. Biotech. 8(17): 24822489.

[6]. Benton, J. J. R., B. wolf and H. A. Mills. 1991. Plant Analysis Hand Book. A practical sampling, analysis and interpretation guide. Micro publ. Inc. USA.

[7]. Bhanavase, D.B., and P.L. Patil. 1994. Effect of molybdenum on nodulation in gram. J. Maharashtra. Agric. Univ. 19: 127-129.

[8]. Boto, J. Valenciano and V. Marcelo (2010) Response of chickpea (Cicer arietinum L.) yield to zinc, boron and molybdenum application under pot conditions Spanish J. Agric. Res. 8(3), 797-807.

[9]. Brikics, S., Z. Milakovic, A. Kristek, M. Antunovic. 2004. Pea yield and its quality depending on inoculation, nitrogen and molybdenum fertilization. Plant, Soil and Environ. 50(1): 39-45.

[10]. Cottenie, A. 1980. Soil and plant testing as a basis of fertilizer recommendations. Food and Agriculture Organization. FAO. Soil Bull. 38(2): 64-67.

[11]. Cutcliffe, J. A. 1986. Effects of boron, molybdenum and lime on yield and leaf tissue nutrient concentration of green peas. Can. J. Plant Sci. 66: 971-976.

[12]. F.A.O. 1984. Legume inoculants and their use. FAO., U.N. Rome, Italy, p. 1-63.

[13]. Gee, G. W. and J. W. Budr. 1982. Particle size analysis. pp. 383-411. In: Methods of Soil Analysis. Physical and Mineralogical Properties. Part 1. Klute, A. (ed) $2^{\text {nd }}$. Ed. Agron. 9. Am. Soc. Agron. Inc. Wisconsin, USA

[14]. Graham RD, Stangoulis JRS (2005) Molybdenum and disease. In:Mineral nutrition and plant diseases (Dantoff L, Elmer W, Huber D.Eds) St. Paul, MN: APS Press.

[15]. Hageman R.V., Burris R.H. (1978): Nitrogenase and nitrogenase reductase associate and dissociate with each catalytic cycle. Proc. Nat. Acad. Sci. U.S.A., 75: 2699-2702. 
[16]. Haque, I., R.T. odell, W.M. Walker, and C.S. Kamara. 1979. Micronutrients cation survey of lowland rice in Syria Leone. Commun. Soil Sci. Plant Anal. 10: 981-992.

[17]. Isaac R. and J.D. Kerber. 1971. Atomic absorption and flame photometry: Techniques and uses in soil, plant and water analysis. In: Instrumental methods for analysis of soil and plant tissue. M. L. Walsh. (ed). Soil sci. soc. Am. Madison, WI, USA.

[18]. Islam, M.A., U.K. Saha, M.S. Islam, and R.R. Saha. 1995. Fertilizing chickpea for high yield with special emphasis on boron and molybdenum in grey flood plain soils of Bangladesh. Ann. Bangladesh Agric. 5: 43-49.

[19]. Johansen L. M. A. Rondon. J. Ramírez and M. Hurtado. 2007. Biological nitrogen fixation by common beans (Phaseolus vulgaris L.) increases with bio-char additions. Biol. Fert. Soil. 43: 699-708.

[20]. Jongruaysup S., Ohara G.W., Dell B. and Bell R.W. (1993): Effects of low molybdenum seed on nodule initiation, development and $\mathrm{N}_{2}$ fixation in black gram (Vigna mungo L). Plant-Soil, 156: $345-348$.

[21]. Kaiser, B. N., K. Gridley, J. N. Brady, T. Phillips and S. D. Tyerman. 2005. The role of molybdenum in agricultural plant production. J. Sci. Annals of Botany 96(5): 745-754.

[22]. Katyal, J. and N. S. Randhawa. 1983. Micronutrients. FAO. Fertilizer and Plant Nutrition, Bulletin No. 7. United Nation.

[23]. Kevresan, S.M. Popovic and J. Kandrac. 2001. Nitrogen and protein metabolism in young pea plants as affected by different concentrations of nickel, cadmium, lead and molybdenum. J. Plant Nutr. 24: 1633-1644.

[24]. Kim, J. and D.C. Rees. 1992. Structural models for the metal centers in the nitrogenase molybdenum-iron protein. Chemistry and Chemical Engineering, California Institute of Technology, Pasadena.257 (5077):1677-1682.

[25]. Kothari M. L. 2002. Effect of modes and levels of molybdenum application on grain yield protein content and nodulation of chickpea grown on loamy sand soil. Commu. Soil Sci. Plant Anal. 33(15): 18-23.

[26]. Kumpawat, B.S., and S. Manohar. 1994. Effect of Rhizobium inoculation, phosphorus and micronutrients on nodulation and protein content of gram. Madras Agric. J. 81: 630- 631.

[27]. Landge, S. K., S. U. Kakade, P. D. Thakare., A. P. Karunakar and D. J. Jiotode. 2002. Response of soybean to nitrogen and phosphorus. Pak. J. Genotypes Sci. 3(3): 653-655.

[28]. Mahavir Singh, S.K Chaudhary, S.R. Sharma and M.S. Rathore (2004) Effect of some micronutrients on content and uptake by chickpea (Cicerarletinum) Agric. Sci. Digest, 24 (4) : $268-270$.

[29]. Marschner, H., M. Haussling and E. George. 1995. Ammonium and nitrate uptake rates and rhizosphere pH in non-mycorrhizal roots of Norway spruce (Picea abies L.) Karst. Trees. 5:14-21.

[30]. McLean, E. O. 1982. Soil pH and lime requirement. Pp. 199-224. In: Methods of Soil Analysis. Physical and Mineralogical Properties. Part 2. Page, A. L., M. H. Miller and D. R. Keeny. (eds.) $2^{\text {nd }}$. Ed. Am. Soc. Agron. Inc. Madison, WI, USA.

[31]. Meagher,W. R., M. Johnson and P. R. Stout. 1991. Molybdenum requirement of leguminous plants supplied with fixed nitrogen. Plant Physiol. 27(2): 623-629.

[32]. Mulvaney, R. L. and H. M. Brown. 1996. A soil organic nitrogen fraction that reduces the need for nitrogen fertilization. Soil Sci. Soc. Am. J. 65: 1164-1172.

[33]. Nautiyal N., S. Singh and C. Chatterjee. 2005. Seed reserves of chickpea in relation to molybdenum supply. J. Sci. Food Agric.85:860-864.

[34]. Nelson, D. W. and L. E. Sommers. 1996. Total carbon, organic carbon and organic matter. pp. 961-1010. In: Methods of Soil analysis Part 3. Sparks, D. L. (ed) Soil Sci. Soc. Am. Inc. Book Series No. 5. Madison, Wisconsin, USA.

[35]. Nenova, V. 2006 Effect of iron supply on growth and photosystem and efficiency of pea plants. Gen. Appl. Plant Physiol. Special Issue.81-90.

[36]. Rabbani M.G., A.R. Solaiman, K.M. Hossain and T. Hossain. 2005. Effects of Rhizobium Inoculant, nitrogen, phosphorus and molybdenum on nodulation, yield and seed protein in pea. Kor. J. Genotypes Sci. 50(2): 112-119.

[37]. Rhoades, J. D. 1982. Cation exchange capacity. pp. 149-157. In: Methods of Soil Analysis. Physical and Mineralogical Properties. Part 2. Page, A. L. M. H.Miller and D. R. Keeny. (eds.) $2^{\text {nd }}$. Ed. Am. Soc. Agron. Inc. Madison, WI, USA.

[38]. Rondon, M. A., J. Lehmann, J. Ramírez and M. Hurtado. 2007. Biological nitrogen fixation by common beans (Phaseolus vulgaris L.) increases with biochar additions Biol. Fert. Soils 43:699-708.

[39]. Saraie, J.M. Kitagawa, A. Shinohara and T. Tanaka. 1983. Heteroepitaxial growth of $\mathrm{ZnSO}_{4}$ by a close-spaced technique: incorporation and morphology. J. Crystal growth. 63(2): 321-336.

[40]. Sarawgi, S. K. P.K . Tiwari . and R.S Tripathi.. 2000 . Growth, nodulation and yield of chickpea as influenced phosphorus. Bacterial culture and micronutrients under rainfed condition. Madras Agric. J. 86: 181-185.

[41]. Srivastava, S. N. L. and S. C. Varma. 1985. Effect of nitrogen, phosphorus and molybdenum fertilization on growth, nodulation and residual fertility in field pea. Ind. J. Agric. Res. 19(3): 131-137.

[42]. Sawires, E.S. 2001. Effect of phosphorus fertilization and micronutrients on yield and yield components of chickpea (Cicer arietinum. ) Ann . Agric . Sci. Cairo. 46: 155-164.

[43]. Schwenke, G.D., M.B. Peoples, G.L. Turner, and D.F Her ridge. 1998. Doses nitrogen fixation of commercial, dryland chickpea and faba bean genotypess in North West New South Wales maintain or enhance soil nitrogen . Aust. J .Exp. Agric. 38 : 61-70.

[44]. Shah, Z.,S.H . Shah, M. Aslam, S. Ali,D.F. Herridge, M.B. Peoples, and M. T.Jan. 1998. Pakistan's Agriculture Cereal and Legume Production. J. Univ. Wales 75: 89-97.

[45]. Shil, S. Noor And M.A. Hossain (2007) Effects of Boron and Molybdenum on the Yield of Chickpea J Agric Rural Dev 5(1\&2), $17-24$.

[46]. Singh,V., G.P. Singh, and V. Singh.1994. Effect of applied potassium and molybdenum on yield and composition of chickpea. J. Potassium. Res. 10: 411-414.

[47]. Srivastava, S. N. L. and S. C. Varma. 1995. Effect of nitrogen, phosphorus and molybdenum fertilization on growth, nodulation and residual fertility in field pea. Ind. J. Agric. Res. 19(3): 131-137.

[48]. Steel, R. G. D., Torrie J. H. and Dickey, D. A. 1997.Principle and Procedure of Statistics.A Biometrical Approach. $3^{\text {rd }}$. (ed). McGraw Hill Companies, Inc. New York, USA.

[49]. Tahir, M., A. Ali, N. Aabidin, M. Yaseen and H. Rehman. 2011. Effect of molybdenum and seed inoculation on growth, yield and quality of mungbean. Genotypes and Environment. 2(2): 37-40.

[50]. Truong, H. H. and C. Duthion. 1993. Time of flowering of pea (PisumSatirum L.) as a function of leaf appearance rate and node of flower. Ann. Botany. 72: 133-142.

[51]. Valenciano, J. A. Boto and V. Marcelo (2010) Response of chickpea (Cicer arietinum L.) yield to zinc, boron and molybdenum application under pot conditions Spanish J. Agric. Res. 8(3), 797-807.

[52]. Verma, L.P., P.C. Ram, and B.R. Maurya. 1988. Response of chickpea to phosphorus and molybdenum of eastern Uttar Pradesh, India. Int. Chickpea Newsletter. 18, 31-33. 
[53]. Vieira, R. F., E. J. Cardoso, and C. Cassini. 1998. Foliar application of molybdenum in common beans. I. Nitrogenase and reductase activities in a soil of high fertility. J. Plant Nutr. 21:169-180.

[54]. Walsh, L. M and J. D. Beaton. 1977. Soil Testing and Plant Analysis. Soil Sci. Soc. Am. Inc. Madison, USA.

[55]. Wankhade, .S.G., R.C. Dakhore, S.S. Wanjari, D.B. Patil, N.R. Potdukhe, and R.W. Ingle. 1996. Response of genotypess to micronutrients. Ind. J. Agric. Res. 3: 164-168.

[56]. Westermann. D. T. 2005. Nutritional requirements of potatoes. Am. J. Potato Res. 82: 301-307.

[57]. Williams R.J.P, Frausto da Silva J.J.R. 2002. The involvement of molybdenum in life. Bioch.and Biophy. Res. Commun.292: 293-299.

[58]. Wolfe,M. 1994.The Effect of molybdenum upon the nitrogen metabolism of Anabaena cylindrica. Ann. Bot. 18 (3): $309-325$.

[59]. Zahid, M.A., A. Rashid, and J. Din . 2000. Balanced nutrient management in chickpea. Int. Chickpea and Pigeon Pea Newsletter. 7: 24-26.

[60]. Zaman, M. Abdul Mazid and Golam Kabir (2011) effect of rhizobium inoculant on nodulation, yield and yield traits of chickpea (Cicer arietinum L.) in four different soils of greater rajshahi J. Life Earth Sci., Vol. 6: 45-50.

[61]. Zaroug, and N. Munns. 1997. Nodulation, nitrogen fixation, leaf area, and sugar content in lablab purpureus as affected by sulfur nutrition by plant and soil. Ann. Botany. 53: 319-32. 